\title{
p.Arg72Pro polymorphism of P53 and breast cancer risk: a meta-analysis of case- control studies
}

\author{
Brehima Diakite ${ }^{1,23^{*}}$ (D), Yaya Kassogue 1,2,3, Guimogo Dolo ${ }^{1,2}$, Jun Wang ${ }^{3,4}$, Erin Neuschler ${ }^{5}$, Oumar Kassogue, ${ }^{1,2}$, \\ Mamadou L Keita ${ }^{2}$, Cheick B Traore, ${ }^{1,2}$, Bakarou Kamate ${ }^{1,2}$, Etienne Dembele ${ }^{3,4}$, Sellama Nadifi ${ }^{6}$, Robert L Murphy ${ }^{3,4}$, \\ Seydou Doumbia ${ }^{1,2}$, Lifang $\mathrm{Hou}^{3,4+}$ and Mamoudou Maiga ${ }^{1,3,4+}$
}

\begin{abstract}
Background: The effect of the p.Arg72Pro variant of the P53 gene on the risk of development ofbreast cancer remains variable in populations. However, the use ofstrategies such aspoolingage-matched controls with disease may provide a consistent meta-analysis. Our goal was to perform a meta-analysis in order to assess the association of p.Arg72Pro variant of P53 gene with the risk of breast cancer.

Methods: Databases such as PubMed, Genetics Medical Literature, Harvard University Library, Web of Science and Genesis Library were used to search articles. Case-control studies with age-matched on breast cancer havingevaluated the genotype frequencies of the TP53 p.Arg72Pro polymorphism were selected. The fixed and random effects (Mantel-Haenszel) were calculated using pooled odds ratio of $95 \% \mathrm{Cl}$ to determine the risk of disease. Inconsistency was calculated to determine heterogeneity among the studies. The publication bias was estimated using the funnel plot.
\end{abstract}

Results: Twenty-one publications with 7841 cases and 8876 controls were evaluated in this meta-analysis. Overall, our results suggested that TP53 p.Arg72Pro was associated with the risk of breast cancer for the dominant model $(\mathrm{OR}=1.09,95 \% \mathrm{Cl}=1.02-1.16, P=0.01)$ and the additive model $(\mathrm{OR}=1.09,95 \% \mathrm{Cl}=1.01-1.17, P=0.03)$, but not for the recessive model $(\mathrm{OR}=1.07,95 \% \mathrm{Cl}=0.97-1.18, P=0.19)$. According to the ethnic group analysis, Pro allele was associated with the risk of breast cancer in Caucasians for the dominant model and additive model $(P=0.02)$, and Africans for the recessive model and additive model $(P=0.03)$.

Conclusions: This meta-analysis found a significant association between TP53 p.Arg72Pro polymorphism and the risk of breast cancer. Individuals carrying at least one Pro allele were more likely to have breast cancer than individuals harboring the Arg allele.

Keywords: P53 gene, p.Arg/pro polymorphism, Breast cancer, Meta-analysis

\footnotetext{
* Correspondence: br.diakite@yahoo.fr

${ }^{+}$Lifang Hou and MamoudouMaiga are Last author.

${ }^{1}$ Faculty of Medicine and Odontostomatology, 1805, Université des Sciences,

des Techniques et des Technologies Sciences de Bamako (USTTB),

Hamdallaye ACl, 2000 Bamako, Mali

${ }^{2}$ Teaching Hospital Center of Point G, 333 Bamako, Mali

Full list of author information is available at the end of the article
}

(c) The Author(s). 2020 Open Access This article is licensed under a Creative Commons Attribution 4.0 International License, which permits use, sharing, adaptation, distribution and reproduction in any medium or format, as long as you give appropriate credit to the original author(s) and the source, provide a link to the Creative Commons licence, and indicate if changes were made. The images or other third party material in this article are included in the article's Creative Commons licence, unless indicated otherwise in a credit line to the material. If material is not included in the article's Creative Commons licence and your intended use is not permitted by statutory regulation or exceeds the permitted use, you will need to obtain permission directly from the copyright holder. To view a copy of this licence, visit http://creativecommons.org/licenses/by/4.0/. The Creative Commons Public Domain Dedication waiver (http://creativecommons.org/publicdomain/zero/1.0/) applies to the data made available in this article, unless otherwise stated in a credit line to the data. 


\section{Background}

Breast cancer is a multifactorial disease which constitutes a major public health problem [1]. In 2018, the World Health Organization reported that 2.09 million new cases of breast cancer were detected [1] compared to 1.38 million cases in 2008 [2]. It is the leading cause of death in women around the world. It should be noted that the incidence of breast cancer differs among different populations around the world [1]. Over the past decades, major advances have been made in understanding the pathology of breast cancer at the molecular level, including the involvement of certain genes associated with the development of the disease such as BRCA1, BRCA2 and P53 which produce tumor suppressor proteins and participate in damaged DNA repair [3-5]. P53 plays a key role in the regulation of cell proliferation and apoptosis. The P53 protein is essential for maintaining the integrity of the cell and its components. In human cancers, mutated P53 produces abnormal proteins that alter or inhibit transcriptional regulation [6]. As a result, the stress response, cell cycle as well as apoptosis are affected. Inactivation or mutation of P53 gene would lead in linkage disequilibrium in the DNA sequence, which, associated with chromosomal aberrations induce the appearance of genomic instability and later the development of cancer $[7,8]$. The molecular signature of human cancers shows that this gene is frequently observed in its mutated form [9]. P53 has been mapped on chromosome $17 p 13$ and contains 11 exons. Several single nucleotide polymorphisms (SNP) have been identified and the most studied variant is the substitution of Arginine by Proline at position 72 in exon 4. Studies carried out on different populations around the world have shown that this SNP is associated with the development of numerous diseases including cancers $[10,11]$. It should be noted that, many association studies have examined the relationship between the SNP p.Arg72Pro of P53 gene and the risk of breast cancer, however, the reports from these studies remain conflicting as some studies have shown that p.Arg72Pro is associated with the risk of breast cancer, while others found no association. Menzel et al. 2004 [12] and Akkiprik et al. 2009 [13] in their investigations showed a link between p.Arg72Pro and the risk of breast cancer. However, other authors who carried out a case-control study in which participants ages were not matched in a similar population, have concluded that p.Arg72Pro was not associated with the risk of breast cancer [14]. These different results with diverging conclusions can be explained by a very strong heterogeneity in allele and genotype distribution of p.Arg72Pro of the P53 gene. This heterogeneity may be related not only to the geographic and ethnic origin [15-17] but also to the study design such as non-agematched case-control studies. Based on these above observations, we hypothesized that the p.Arg72Pro polymorphism of P53 gene may represent a potentially important genetic marker, contributing to breast cancer susceptibility in Caucasian, Asians and Africans. The present meta-analysis included only age-matched casecontrol studies in order to statistically decrease the heterogeneity between the studies, to qualitatively assess the effect of p.Arg72Pro on the risk of breast cancer. We have performed an independent two-stage meta-analysis; overall and sub-group analysis.

\section{Methods \\ Literature search}

The Pubmed Genetics Medical Literature Database, the Harvard University Library, and the Web of Science and Genesis Library were used to identify available articles published in English. The keywords "P53", "p.Arg72Pro" and "polymorphism" or "mutation" or "gene" and "breast cancer"cited in the genetic association studies were used to detect and select scientific manuscripts in these databases. We also reviewed references cited in these studies to identify additional articles that were not identified by our research in the databases.

\section{Inclusion criteria}

The inclusion criteria included: (1) published casecontrol studies as an original article to evaluate the association between p.Arg72Pro of the P53 gene and the risk of breast cancer, (2) full manuscript available, (3) casecontrol study with age-matched, (4) distribution of genotype respecting Hardy-Weinberg equilibrium (HWE) in controls, (5) availability of the three genotypic frequencies (Arg/Arg, Arg/Pro and Pro/Pro) in the case and control groups. (6) Study no influencing the pooled odd ratio (OR) values. Three investigators independently evaluated each study to determine eligibility.

\section{Data extraction}

The data were collected by an investigator and verified by a second investigator to reach consensus on all points. First author, year of publication, country, ethnicity of study population, sample size, age-matched, distribution of genotype andalleles, as well as the recalculation of HWE in controls were extracted from the eligible studies. A third reviewer made a contradictory assessment to reconcile the assumptions. The data of controls evaluated with p.Arg72Pro variant were included in this meta-analysis.

\section{Statistical analysis}

$\mathrm{Chi}^{2}$ analysis with a significance level of $P<0.05$ was used to evaluate whether p.Arg72Pro polymorphism distribution of the P53 gene in controls fits HWE. The association between the p.Arg72Pro and the risk of breast 
cancer was evaluated by the Odd ratio (OR) of 95\% CI. We evaluated the strength of association between the p.Arg72Pro polymorphism of P53 gene and the risk of breast cancer using different genetic models, including the dominant (Pro/Pro + Arg/Pro vs. Arg/Arg), recessive (Pro/Pro vs. Arg/Arg + Arg/Pro) and the additive (Pro vs. $A r g)$. Heterogeneity among the studies was assessed by $\mathrm{I}^{2}$ statistical test $[18,19]$. If $\mathrm{I}^{2}>50 \%$ (presence of heterogeneity), the random effects model was used to calculate the overall OR, otherwise in case of lack of heterogeneity, the fixed effects method was used. We also have examined the funnel plot to determine publication bias [20]. All statistical analyses were performed with Review Manager Software version 5.1.

\section{Results}

\section{Characteristic of eligible studies}

Figure 1 summarizes the process of selecting studies that the inclusion criteria. In sum, 21 eligible age-matched case-control studies were selected for the pooled OR analyses. Genotype distribution of the control population that met HWE was a minimum requirement for studies to be retained for the meta-analysis. Out of the 21 studies (7841cases and8876 controls), eleven were Caucasians [12-14, 23-28, 36, 37], nine were Asians [21, 2935, 38] and one was African [22] (Table 1).

\section{Quantitative analysis}

Table 2 shows pooled ORs and heterogeneity testresults of the association between the TP53 p.Arg72Pro polymorphism and the risk of breast cancer. Overall, a slightly association of TP53 p.Arg72Pro polymorphism with the risk of breast cancer was observed for the dominant $(\mathrm{OR}=1.09,95 \% \mathrm{CI}=1.02-1.16, P=0.01$, Fig. 2$)$ and additive $(\mathrm{OR}=1.09,95 \% \mathrm{CI}=1.01-1.17, P=0.03$, Fig. 3) models, but not for the recessive model $(\mathrm{OR}=$ $1.07,95 \% \mathrm{CI}=0.97-1.18, P=0.19$, Fig. 4). In the subgroup analyzes, except the recessive model $(\mathrm{OR}=1.18$, $95 \% \mathrm{CI}=0.96-1.44 ; P=0.12$ ), we noted a moderate association of p. Arg72Pro with the risk of breast cancer for the dominant $(\mathrm{OR}=1.09,95 \% \mathrm{CI}=1.01-1.17, P=$ $0.02)$ and additive $(\mathrm{OR}=1.07,95 \% \mathrm{CI}=1.01-1.14, P=$ 0.02) models in Caucasians (Fig. 5). When considering the Asian population, the different genetic models showed no trend (recessive: $\mathrm{OR}=1.01,95 \% \mathrm{CI}=0.87$ 1.17, $P=0.88$; dominant: $\mathrm{OR}=1.06,95 \% \mathrm{CI}=0.94-1.20$; $P=0.33$; additive; $\mathrm{OR}=1.06,95 \% \mathrm{CI}=0.91-1.23, P=$ 0.46) (Fig. 6). The only eligible African study showed that the TP53 p.Arg72Pro polymorphism is highly associated with the risk of breast cancer as well in the recessive model $(\mathrm{OR}=2.14,95 \% \mathrm{CI}=1.08-4.23, P=0.03)$ than in the additive model $(\mathrm{OR}=1.49,95 \% \mathrm{CI}=1.03$ 2.16, $P=0.03)$.

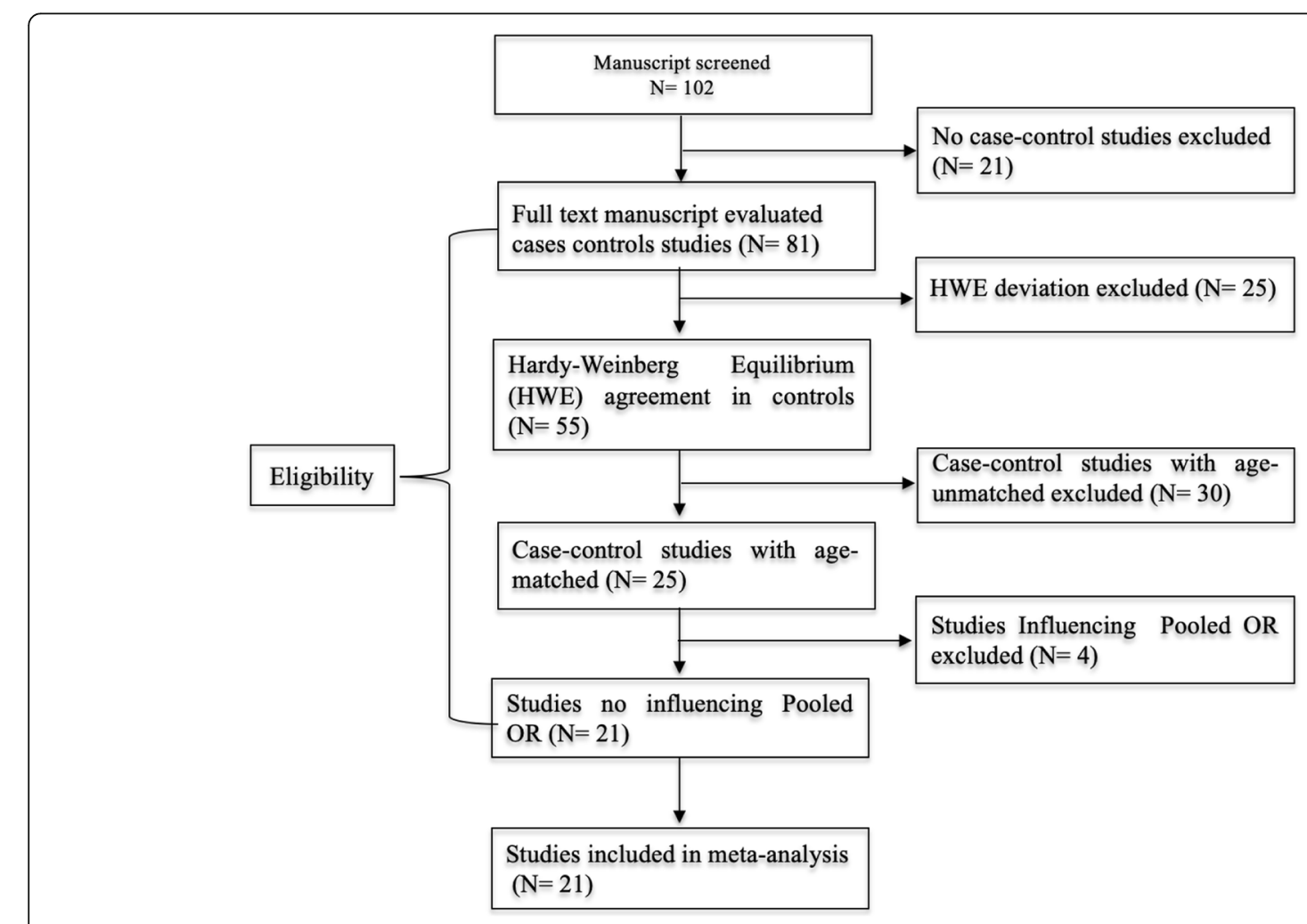

Fig. 1 Flow diagram of the studies evaluated for meta-analysis 
Table 1 Genotypes distribution of TP53 p.Arg72Pro in breast cancer cases and controls

\begin{tabular}{|c|c|c|c|c|c|c|c|c|c|c|}
\hline \multirow[b]{2}{*}{ Authors } & \multirow[b]{2}{*}{ Ethnicity } & \multirow[b]{2}{*}{$\mathbf{N}$} & \multicolumn{3}{|l|}{ Cases } & \multirow[b]{2}{*}{$\mathbf{N}$} & \multicolumn{3}{|l|}{ Controls } & \multirow[b]{2}{*}{ HWE } \\
\hline & & & Arg/Arg & Arg/Pro & Pro/Pro & & Arg/Arg & Arg/Pro & Pro/Pro & \\
\hline Akkiprik et al. 2009 [13] & Caucasian & 95 & 25 & 50 & 20 & 107 & 46 & 49 & 12 & Yes \\
\hline Alshatwi et al. 2012 [21] & Asian & 100 & 22 & 52 & 26 & 100 & 32 & 51 & 17 & Yes \\
\hline Ayoubi et al. 2018 [22] & African & 125 & 55 & 42 & 28 & 126 & 65 & 46 & 15 & Yes \\
\hline Buyru et al. 2003 [23] & Caucasian & 115 & 64 & 39 & 12 & 63 & 26 & 28 & 9 & Yes \\
\hline Cherdyntseva et al. 2012 [24] & Caucasian & 388 & 184 & 162 & 42 & 275 & 148 & 100 & 27 & Yes \\
\hline Costa et al. 2008 [25] & Caucasian & 175 & 98 & 61 & 16 & 212 & 124 & 70 & 18 & Yes \\
\hline Cox et al. 2007 [26] & Caucasian & 1477 & 804 & 569 & 104 & 2224 & 1255 & 838 & 131 & Yes \\
\hline Denisov et al. 2009 [27] & Caucasian & 297 & 148 & 124 & 25 & 275 & 147 & 99 & 29 & Yes \\
\hline Ebner et al. 2010 [28] & Caucasian & 263 & 138 & 108 & 17 & 254 & 137 & 103 & 14 & Yes \\
\hline Hossain et al. 2016 [29] & Asian & 125 & 54 & 42 & 29 & 125 & 61 & 51 & 13 & Yes \\
\hline Isakova et al. 2017 [30] & Asian & 117 & 57 & 50 & 10 & 102 & 53 & 36 & 13 & Yes \\
\hline Katiyar et al. 2003 [31] & Asian & 77 & 20 & 51 & 6 & 41 & 9 & 24 & 8 & Yes \\
\hline krivokuca et al. 2014 [14] & Caucasian & 155 & 87 & 58 & 10 & 114 & 62 & 45 & 7 & Yes \\
\hline Li et al. 2002 [32] & Asian & 28 & 11 & 10 & 7 & 50 & 10 & 26 & 14 & Yes \\
\hline Ma et al. 2006 [33] & Asian & 404 & 149 & 178 & 77 & 472 & 150 & 222 & 100 & Yes \\
\hline Menzel et al. 2004 [12] & Caucasian & 302 & 158 & 114 & 30 & 475 & 275 & 170 & 30 & Yes \\
\hline Sharma et al. 2014 [34] & Asian & 200 & 47 & 103 & 50 & 200 & 67 & 91 & 42 & Yes \\
\hline Song et al. 2009 [35] & Asian & 1110 & 341 & 547 & 222 & 1097 & 355 & 514 & 228 & Yes \\
\hline Sprague et al. 2007 [36] & Caucasian & 1653 & 909 & 644 & 100 & 1854 & 1021 & 704 & 129 & yes \\
\hline Wang-Gohrke et al. 2002 [37] & Caucasian & 552 & 282 & 221 & 49 & 543 & 300 & 203 & 40 & yes \\
\hline Zhang et al. 2007 [38] & Asian & 83 & 21 & 45 & 17 & 167 & 47 & 87 & 33 & yes \\
\hline
\end{tabular}

$N$ Number, HWE, Hardy-Weinberg Equilibrium

Table 2 Distribution of TP53 p.Arg72Pro polymorphism according to the different genetic models

\begin{tabular}{|c|c|c|c|c|c|c|c|}
\hline \multirow[b]{2}{*}{ Group } & \multirow[b]{2}{*}{$\mathbf{N}$} & \multirow{2}{*}{$\begin{array}{l}\text { Sample size } \\
\text { Cases/Controls }\end{array}$} & \multirow{2}{*}{$\begin{array}{l}\text { Genetic } \\
\text { Models }\end{array}$} & \multicolumn{2}{|l|}{ Pooled } & \multicolumn{2}{|c|}{ Heterogeneity } \\
\hline & & & & OR $(95 \% \mathrm{Cl})$ & $P$-value & $\mathbf{I}^{2}$ & Phet \\
\hline \multirow[t]{4}{*}{ Overall } & 21 & $7841 / 8876$ & & & & & \\
\hline & & & Dominant & 1.09 (1.02-1.16) FE & 0.01 & $31 \%$ & 0.09 \\
\hline & & & Recessive & $1.07(0.97-1.18) \mathrm{FE}$ & 0.19 & $36 \%$ & 0.05 \\
\hline & & & Additive & 1.09 (1.01-1.17) FE & 0.03 & $47 \%$ & 0.01 \\
\hline \multirow[t]{4}{*}{ Caucasian } & 11 & $5472 / 6396$ & & & & & \\
\hline & & & Dominant & 1.09 (1.01-1.17) FE & 0.02 & $27 \%$ & 0.19 \\
\hline & & & Recessive & $1.09(0.95-1.25) \mathrm{FE}$ & 0.22 & $10 \%$ & 0.34 \\
\hline & & & Additive & $1.07(1.01-1.14) \mathrm{FE}$ & 0.02 & $39 \%$ & 0.09 \\
\hline \multirow[t]{4}{*}{ Asian } & 9 & $2244 / 2354$ & & & & & \\
\hline & & & Dominant & $1.06(0.94-1.20) \mathrm{FE}$ & 0.33 & $45 \%$ & 0.07 \\
\hline & & & Recessive & $1.01(0.87-1.17) \mathrm{FE}$ & 0.88 & $48 \%$ & 0.05 \\
\hline & & & Additive & $1.06(0.91-1.23) \mathrm{RE}$ & 0.46 & $54 \%$ & 0.03 \\
\hline \multirow[t]{4}{*}{ African } & 1 & $125 / 126$ & & & & & \\
\hline & & & Dominant & $1.36(0.83-2.23)$ & 0.23 & & \\
\hline & & & Recessive & $2.14(1.08-4.23)$ & 0.03 & - & - \\
\hline & & & Additive & $1.49(1.03-2.16)$ & 0.03 & - & - \\
\hline
\end{tabular}




\begin{tabular}{|c|c|c|c|c|c|c|c|c|c|c|}
\hline \multirow{2}{*}{$\begin{array}{l}\text { Study or Subgroup } \\
\text { Akkiprik et al } 2009 \text { [13] }\end{array}$} & \multicolumn{2}{|c|}{ Experimental } & Control & $\begin{array}{l}\text { ol } \\
\text { Total }\end{array}$ & Weight & $\begin{array}{c}\text { Odds Ratio } \\
\text { M-H, Fixed, } 95 \% \mathrm{Cl}\end{array}$ & \multicolumn{4}{|c|}{$\begin{array}{c}\text { Odds Ratio } \\
\text { M-H, Fixed, 95\% CI }\end{array}$} \\
\hline & 70 & 95 & 61 & 107 & $0.8 \%$ & $2.11[1.16,3.83]$ & & & & \\
\hline Alshatwi et al 2012 [29] & 78 & 100 & 68 & 100 & $0.8 \%$ & $1.67[0.89,3.14]$ & & & & \\
\hline Ayoubi et al 2018 [38] & 70 & 125 & 61 & 126 & $1.4 \%$ & $1.36[0.83,2.23]$ & & & - & \\
\hline Buyru et al 2003 [21] & 51 & 115 & 37 & 63 & $1.4 \%$ & $0.56[0.30,1.04]$ & & & & \\
\hline Cherdyntseva et al 2012 [22] & 204 & 388 & 127 & 275 & $3.7 \%$ & $1.29[0.95,1.76]$ & & & - & \\
\hline Costa et al 2008 [23] & 77 & 175 & 88 & 212 & $2.4 \%$ & $1.11[0.74,1.66]$ & & & $\leftarrow$ & \\
\hline Cox et al 2007 [24] & 673 & 1477 & 969 & 2224 & $22.3 \%$ & $1.08[0.95,1.24]$ & & & $=$ & \\
\hline Denisov et al 2009 [25] & 149 & 297 & 128 & 275 & $3.5 \%$ & $1.16[0.83,1.61]$ & & & $\leftarrow$ & \\
\hline Ebner et al 2010 [26] & 125 & 263 & 117 & 254 & $3.3 \%$ & $1.06[0.75,1.50]$ & & & F & \\
\hline Hossain et al 2016 [30] & 71 & 125 & 64 & 125 & $1.5 \%$ & $1.25[0.76,2.06]$ & & & - & \\
\hline Isakova et al 2017 [31] & 60 & 117 & 49 & 102 & $1.4 \%$ & $1.14[0.67,1.94]$ & & & - & \\
\hline Katiyar et al 2003 [32] & 57 & 77 & 32 & 41 & $0.6 \%$ & $0.80[0.33,1.97]$ & & & — & \\
\hline krivokuca et al 2014 [14] & 68 & 155 & 52 & 114 & $1.8 \%$ & $0.93[0.57,1.52]$ & & & - & \\
\hline Li et al 2002 [33] & 17 & 28 & 40 & 50 & $0.6 \%$ & $0.39[0.14,1.08]$ & & & & \\
\hline Ma et al 2006 [34] & 255 & 404 & 322 & 472 & $5.8 \%$ & $0.80[0.60,1.05]$ & & & & \\
\hline Menzel et al 2004 [12] & 144 & 302 & 200 & 475 & $4.3 \%$ & $1.25[0.94,1.67]$ & & & - & \\
\hline Sharma et al 2014 [35] & 153 & 200 & 133 & 200 & $1.7 \%$ & $1.64[1.06,2.54]$ & & & . & \\
\hline Song et al 2009 [36] & 769 & 1110 & 742 & 1097 & $12.2 \%$ & $1.08[0.90,1.29]$ & & & 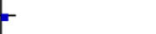 & \\
\hline Sprague et al 2007 [27] & 744 & 1653 & 833 & 1854 & $22.9 \%$ & $1.00[0.88,1.15]$ & & & & \\
\hline Wang-Gohrke et al 2002 [28] & 270 & 552 & 243 & 543 & $6.6 \%$ & $1.18[0.93,1.50]$ & & & - & \\
\hline Zhang et al 2007 [37] & 62 & 83 & 120 & 167 & $1.1 \%$ & $1.16[0.64,2.10]$ & & & & \\
\hline Total $(95 \% \mathrm{Cl})$ & & 7841 & & 8876 & $100.0 \%$ & $1.09[1.02,1.16]$ & & & & \\
\hline Total events & 4167 & & 4486 & & & & & & & \\
\hline $\begin{array}{l}\text { Heterogeneity: } \mathrm{Chi}^{2}=29.00, \mathrm{~d} \\
\text { Test for overall effect: } \mathrm{Z}=2.5 \mathrm{~g}\end{array}$ & $\begin{array}{l}=20(P= \\
(P=0.01\end{array}$ & 0.09 ); & $I^{2}=31 \%$ & & & & 0.01 & 0.1 & 10 & 100 \\
\hline
\end{tabular}

Fig. 2 Forest plots of the association between breast cancer and TP53 p.Arg72Pro polymorphism for the dominant model. The black diamond denotes the pooled OR; blue squares indicate the OR in each study with square sizes inversely proportional to the standard error of the OR; and horizontal lines represent the $95 \% \mathrm{Cl}$

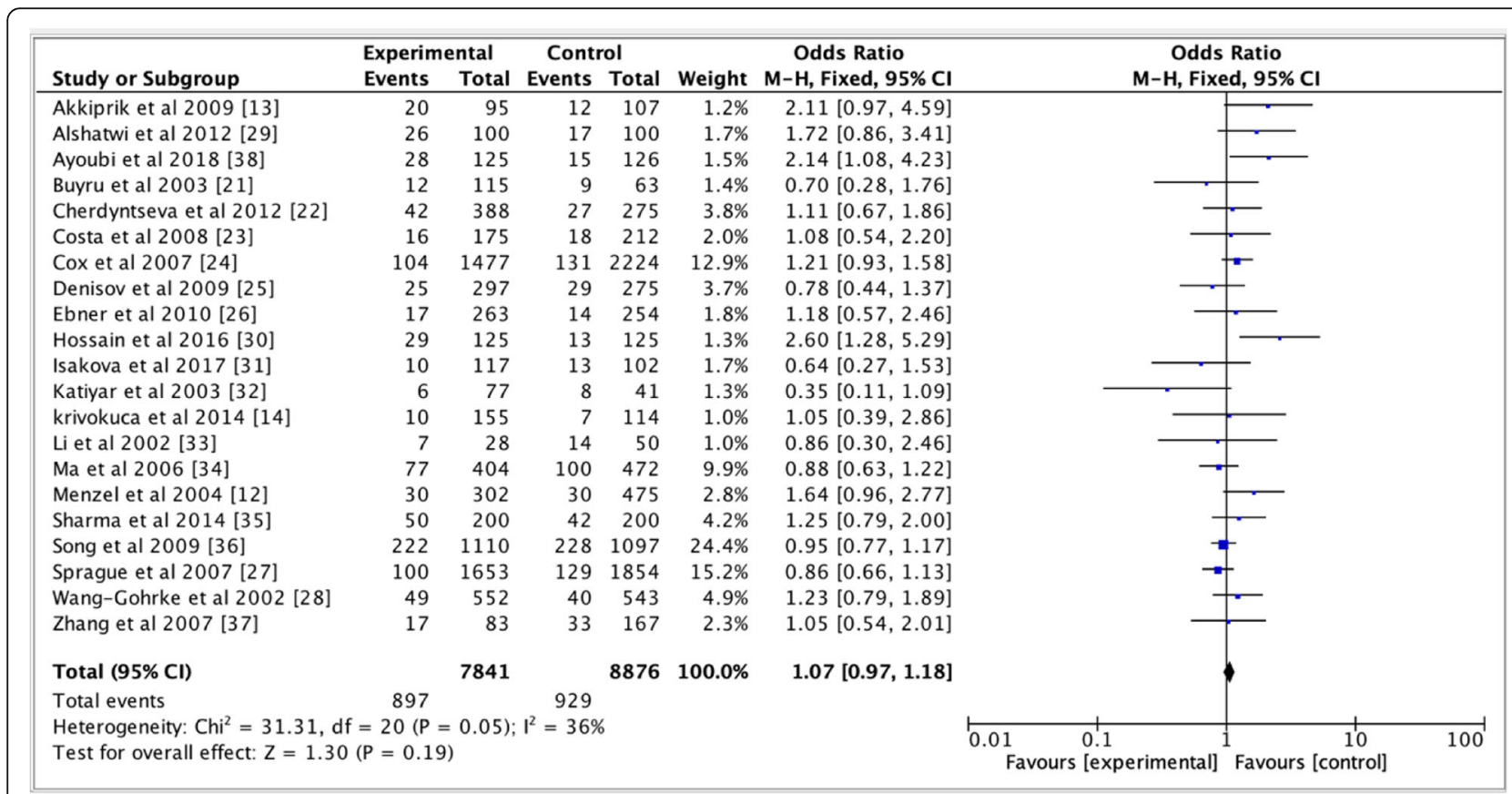

Fig. 3 Forest plots of the association between breast cancer and TP53 p.Arg72Pro polymorphism for the recessive model. The black diamond denotes the pooled OR; blue squares indicate the OR in each study with square sizes inversely proportional to the standard error of the OR; and horizontal lines represent the $95 \% \mathrm{Cl}$ 


\begin{tabular}{|c|c|c|c|c|c|c|c|c|c|}
\hline Study or Subgroup & \multicolumn{2}{|c|}{ Experimental } & \multicolumn{2}{|c|}{ Control } & Weight & $\begin{array}{l}\text { Odds Ratio } \\
\mathrm{M}-\mathrm{H}, \text { Random, } 95 \% \mathrm{Cl}\end{array}$ & \multicolumn{2}{|c|}{$\begin{array}{c}\text { Odds Ratio } \\
\mathrm{M}-\mathrm{H}, \text { Random, } 95 \% \mathrm{Cl}\end{array}$} & \\
\hline Akkiprik et al 2009 [13] & 90 & 190 & 73 & 214 & $2.8 \%$ & $1.74[1.16,2.60]$ & & $\because$ & \\
\hline Alshatwi et al 2012 [29] & 104 & 200 & 85 & 200 & $2.9 \%$ & $1.47[0.99,2.17]$ & & {[} & \\
\hline Ayoubi et al 2018 [38] & 98 & 250 & 76 & 252 & $3.2 \%$ & $1.49[1.03,2.16]$ & & 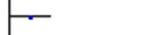 & \\
\hline Buyru et al 2003 [21] & 63 & 230 & 46 & 126 & $2.2 \%$ & $0.66[0.41,1.04]$ & & & \\
\hline Cherdyntseva et al 2012 [22] & 246 & 776 & 154 & 550 & $5.6 \%$ & $1.19[0.94,1.52]$ & & - & \\
\hline Costa et al $2008[23]$ & 93 & 350 & 106 & 424 & $3.8 \%$ & $1.09[0.79,1.50]$ & & 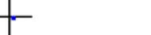 & \\
\hline Cox et al 2007 [24] & 777 & 2954 & 1100 & 4448 & $10.2 \%$ & $1.09[0.98,1.21]$ & & 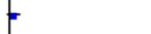 & \\
\hline Denisov et al 2009 [25] & 174 & 594 & 157 & 550 & $5.2 \%$ & $1.04[0.80,1.34]$ & & - & \\
\hline Ebner et al 2010 [26] & 142 & 526 & 131 & 508 & $4.7 \%$ & $1.06[0.81,1.40]$ & & & \\
\hline Hossain et al $2016[30]$ & 100 & 250 & 77 & 250 & $3.2 \%$ & $1.50[1.04,2.17]$ & & $\sigma$ & \\
\hline Isakova et al 2017 [31] & 70 & 234 & 62 & 204 & $2.7 \%$ & $0.98[0.65,1.47]$ & & & \\
\hline Katiyar et al 2003 [32] & 63 & 154 & 40 & 82 & $1.7 \%$ & $0.73[0.42,1.25]$ & & - & \\
\hline krivokuca et al 2014 [14] & 78 & 310 & 59 & 228 & $2.9 \%$ & $0.96[0.65,1.43]$ & & & \\
\hline Li et al 2002 [33] & 24 & 56 & 54 & 100 & $1.2 \%$ & $0.64[0.33,1.24]$ & & & \\
\hline Ma et al 2006 [34] & 332 & 808 & 422 & 944 & $7.1 \%$ & $0.86[0.71,1.04]$ & & & \\
\hline Menzel et al 2004 [12] & 174 & 604 & 230 & 950 & $5.9 \%$ & $1.27[1.01,1.59]$ & & - & \\
\hline Sharma et al 2014 [35] & 203 & 400 & 175 & 400 & $4.7 \%$ & $1.32[1.00,1.75]$ & & F- & \\
\hline Song et al 2009 [36] & 991 & 2220 & 970 & 2194 & $9.7 \%$ & $1.02[0.90,1.15]$ & & & \\
\hline Sprague et al 2007 [27] & 844 & 3306 & 962 & 3708 & $10.2 \%$ & $0.98[0.88,1.09]$ & & & \\
\hline Wang-Gohrke et al 2002 [28] & 319 & 1104 & 283 & 1086 & $7.2 \%$ & $1.15[0.96,1.39]$ & & F & \\
\hline Zhang et al 2007 [37] & 79 & 166 & 153 & 334 & $3.1 \%$ & $1.07[0.74,1.56]$ & & & \\
\hline Total $(95 \% \mathrm{Cl})$ & & 15682 & & 17752 & $100.0 \%$ & $1.09[1.01,1.17]$ & & 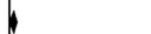 & \\
\hline \multirow{2}{*}{\multicolumn{7}{|c|}{ 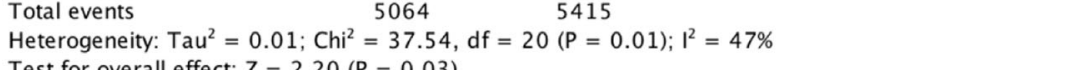 }} & & & \\
\hline & & & & & & & 0.01 & 10 & 100 \\
\hline
\end{tabular}

Fig. 4 Forest plots of the association between breast cancer and TP53 p.Arg72Pro polymorphism for the additive model. The black diamond denotes the pooled OR; blue squares indicate the $\mathrm{OR}$ in each study with square sizes inversely proportional to the standard error of the OR; and horizontal lines represent the $95 \% \mathrm{Cl}$

\section{Sensitive analysis}

To maintain the stability of the meta-analysis after the non-inclusion of deviant studies of HWE, we evaluated the influence of each study on pooled OR. After the exclusion of studies [39-42], no study has shown a significant influence of pooled OR effect and $p$-values for the different genetic models (Table 2).

\section{Sources of heterogeneity}

To avoid large heterogeneity, we excluded studies in which the distribution of genotypes deviated from the HWE equilibrium. The sensitivity analysis overall, showed moderate heterogeneity $\left(\mathrm{I}^{2}<50 \%\right)$ in the recessive and dominant models. We noted the same tendency of heterogeneity when considering all the data $\left(\mathrm{I}^{2}=47 \%\right.$, $P=0.01)$ and among Asians $\left(\mathrm{I}^{2}=54 \%, P=0.03\right)$ for the additive model (Table 2). In addition, we compared the pooled OR of the fixed and random effects, no statistically significant difference was found between the two effects, which supports strongly the consistency of the present study's data.

\section{Publication Bias}

The publication bias was assessed using the funnel plot. After the exclusion of studies deviating from HWE and those influencing the pooled ORs values, no significant publication bias was found in the different genetic models (Fig. 7).

\section{Discussion}

Like other multifactorial diseases, the causes of breast cancer are not known. However, several factors combine their effects for the development of the disease. These factors are of clinical, biological, environmental and genetic origin $[43,44]$. From a genomic point of view, it has been reported that genetic polymorphisms of the $p 53$ gene can influence the development of cancers [45]. However, the mechanism by which these polymorphisms affect cancer development remain unknown. Functionally, these polymorphisms alter alternative splicing and thus affecting mRNA stability and protein synthesis. The normal P53 gene produces a protein that plays a key role in DNA repair, cell cycle control and apoptosis [45]. Through this physiological role P53 acts as a guardian of the genome, preventing the malignant transformation of normal cells. In the event of a mutation, the function of p53 is impaired, leading to the appearance of malignant cells and later cancerous disease [46-48]. It has been reported that the $R 72$ variant of the P53 mutant in addition to influencing the onset of cancer is also associated with a bad prognosis through the rapid onset of metastasis [49].

In the present meta-analysis, we examined the relationship between TP53 p.Arg72Pro polymorphism and the risk of breast cancer. Overall, our findings showed that the dominant and additive models were associated with an increased risk of breast cancer for the carriers of 


\section{Caucasians}

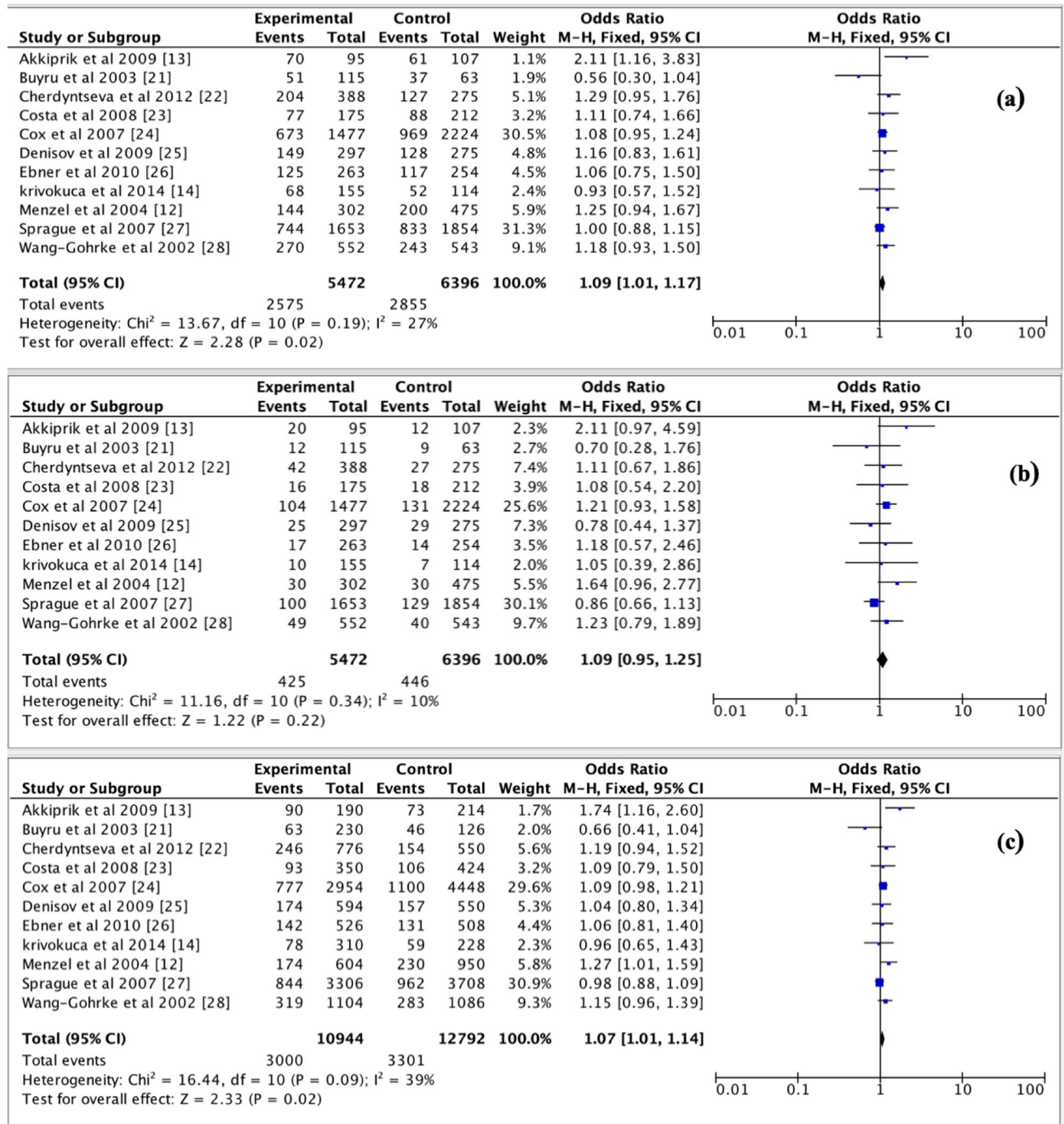

Fig. 5 Forest plots of the association between breast cancer and TP53 p.Arg72Pro polymorphism for the a dominant model, $\mathbf{b}$ recessive model and $\mathbf{c}$ additive model in Caucasians. The black diamond denotes the pooled OR; blue squares indicate the OR in each study with square sizes inversely proportional to the standard error of the OR; and horizontal lines represent the $95 \% \mathrm{Cl}$

72Pro allele. These results corroborate with the data reported from two recent meta-analyzes, the first covering eleven studies with 950 cases and 882 controls in the Asian population [50] and the second performed on the Indian population which covered seven studies with 1249 cases and 1838 controls [51]. These authors in their analysis showed that the dominant and the additive models were associated with the risk of breast cancer. Contrary to our results, other meta-analyzes found conflicting results [52, 53]. The works of Zhuo et al. 2009, Francisco et al. 2011, Ma et al. 2011 and Concalves et al. 2014 also reported a decreased risk of breast cancer with 


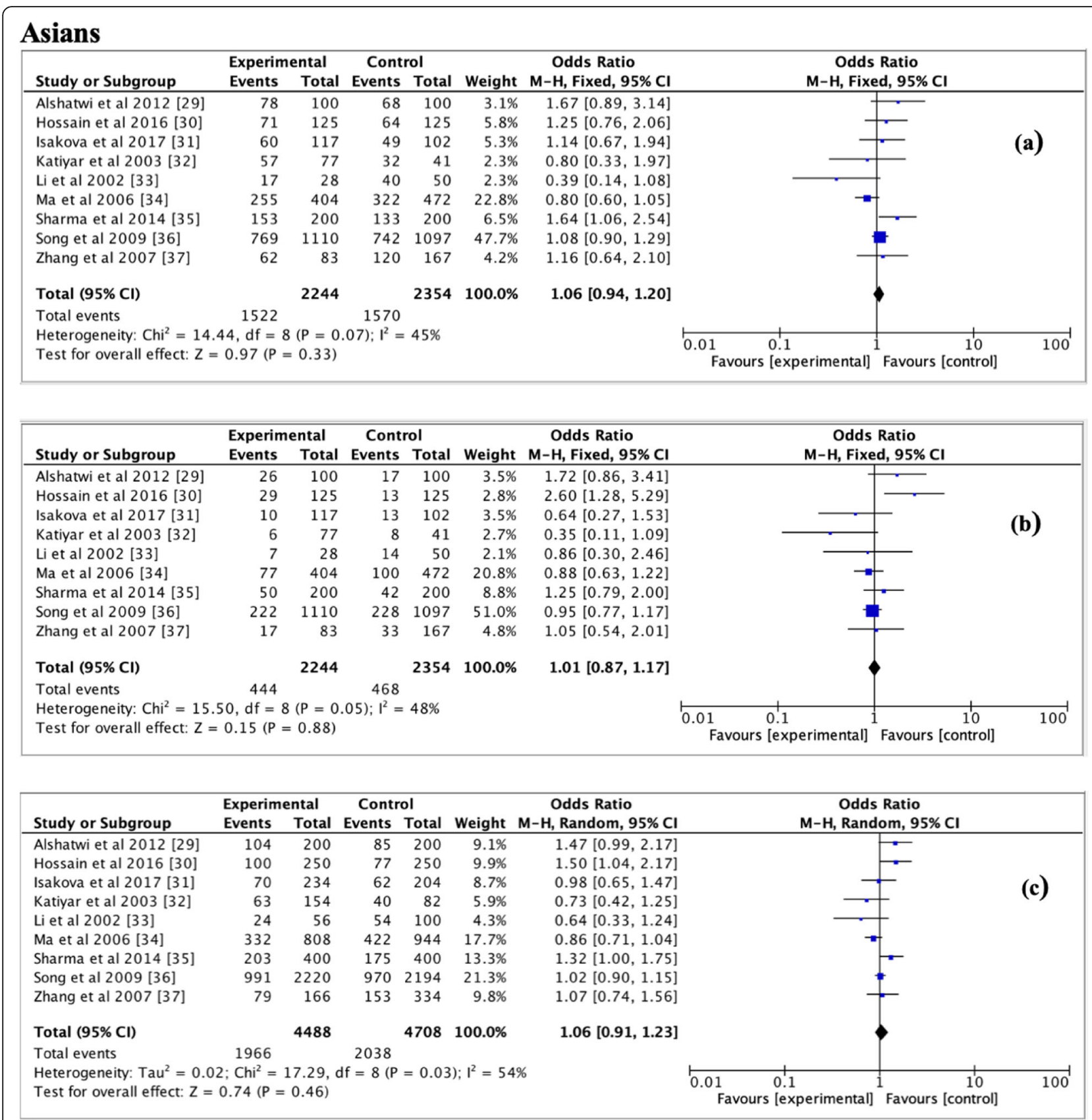

Fig. 6 Forest plots of the association between breast cancer and TP53 p.Arg72Pro polymorphism for the a dominant model, $\mathbf{b}$ recessive model and $\mathbf{c}$ additive model in Asians. The black diamond denotes the pooled OR; blue squares indicate the OR in each study with square sizes inversely proportional to the standard error of the OR; and horizontal lines represent the $95 \% \mathrm{CI}$

the different genetic models applied [54-57]. These differences might be explained by the samples size, types of allelic variant and eligible studies included. In the subgroup analysis, our meta-analysis revealed a high risk of breast cancer with TP53 p.Arg72Pro in Caucasians (dominant model and additive model) and Africans (recessive and additive models). These trends were consistent with previous studies [12, 13, 22] but inconsistent with the findings of other studies [52, 53]. However, Jafrin et al. 2020 concluded that TP53 p.Arg/Pro was associated with the risk of breast cancer in the South Asian population. The difference between the studies could be explained by the ethnicity and study design. The effects of ethnicity may be due to several factors, allelic heterogeneity, gene-gene and gene-environment interaction and linkage disequilibrium [58-61]. In the 


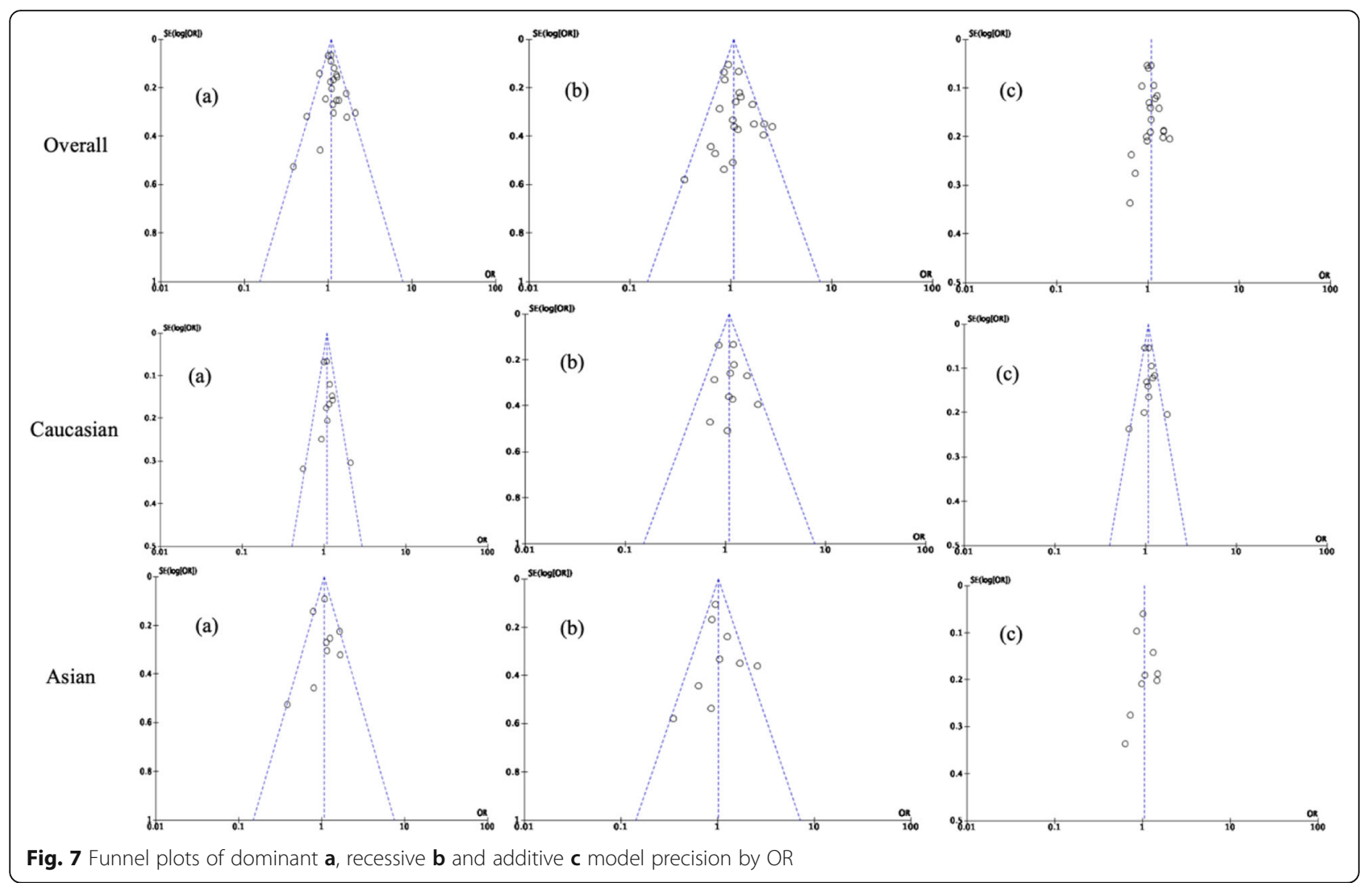

previous meta-analyzes, the selection criteria of studies were not sufficiently robust such as inclusion of the ageunmatched case-control studies and the inclusion of studies with control groups not satisfying HWE [62-75]. The major advantage of the present meta-analysis was the inclusion of a large number of samples, including very selective criteria to measure the strength of the association between this polymorphism in exon 4 of TP53 gene and the risk of breast cancer using different genetic models. However, several limitations need to be highlighted, sample size and small number of casecontrol age-matched studies in ethnic groups.

\section{Conclusion}

In the light of this meta-analysis, we noticed that individuals carrying at least one Pro allele of the P53 gene are more likely to have breast cancer with dominant and additive models than individuals harboring the wild-type Arg allele. Our study further strengthened and confirmed the hypothesis that the P53 gene is usually mutated in about half of breast cancer cases. For the stability and homogeneity of results from meta-analysis, future similar studies should take into account selection criteria for articles such as no deviation from HWE in the control group and the matching of cases and controls according to age.

\section{Supplementary information}

Supplementary information accompanies this paper at https://doi.org/10 1186/s12881-020-01133-8.

Additional file 1. Availability of all data and references with PubMed accession numbers.

\section{Abbreviations}

Arg: Arginine; Cl: Confidence interval; Fig.: Figure; HWE: Hady-Weinberg Equilibrium; $I^{2}$ : Inconsistency; N: Number; OR: Odd ratio; P: P value; Pro: Proline; SNP: Single nucleotide polymorphisms

\section{Acknowledgments}

The authors thank Harvard University, Boston University, Northwestern University, and University of New Mexico (HBNU) Consortium, Global Health, Fogarty International Center and the $\mathrm{NIH}$ for their training support. Wealso thankthe Faculty of Medicine and Odontostomatology of the Universitédes Sciences, Techniques et Technologies de Bamako, the University Clinical Research Center (UCRC-Mali), Intelligence Center of Excellence Mali (ICERMali) particularly Prof Cheick Fantamady Traore, Prof. Mamadou Diakite and Dr. Mamadou Coulibaly for logistical support.

\section{Authors' contributions}

All authors read and approved the final manuscript. Study concept and design: BD, YK, GD, JW, EN, OK, MLK, CBT, BK, ED, SN,SD, LH, MM. Acquisition, analysis and interpretation of data: $B D, Y K, G D, M M$. Drafting of the manuscript: BD with assistance from by $Y K, M M$. Critical revision of the manuscript for important intellectualcontent: JW, EN, SN, GD, SD. Obtaining supervision: LH, RLM.

\section{Funding}

Research reported in this publication was supported by the HBNU Consortium, Fogarty International Center and the National Institutes of Health under Award Number D43 TW010543. The content is solely the 
responsibility of the authors and does not necessarily represent the official views of the National Institutes of Health.

\section{Availability of data and materials}

The dataset analyzed for thisstudyis available from the Additional file 1.

\section{Ethics approval and consent to participate}

Not applicable.

\section{Consent for publication}

Not applicable.

\section{Competing interests}

The authors declare that they have no competing interests.

\section{Author details}

${ }^{1}$ Faculty of Medicine and Odontostomatology, 1805, Université des Sciences, des Techniques et des Technologies Sciences de Bamako (USTTB), Hamdallaye ACl, 2000 Bamako, Mali. ${ }^{2}$ Teaching Hospital Center of Point G, 333 Bamako, Mali. ${ }^{3}$ Preventive Medicine Department, Cancer Epidemiology and Prevention, Northwestern University, Chicago, IL 60611, USA. ${ }^{4}$ Institute for Global Health, Northwestern University, IL60611, Chicago, USA.

${ }^{5}$ Department of Radiology, College of Medicine, University of Illinois at Chicago, Chicago, IL 60612, USA. 'Hassan II University Aïn chock, 20000 Casablanca,19, Rue Tarik Ibnou Ziad, Morocco.

Received: 22 November 2019 Accepted: 24 September 2020 Published online: 19 October 2020

\section{References}

1. Bray F, Ferlay J, Soerjomataram I, Siegel RL, Torre LA, Jemal A. Global cancer statistics 2018: GLOBOCAN estimates of incidence and mortality worldwide for 36 cancers in 185 countries. CA Cancer J Clin. 2018;68:394-424.

2. Ferlay J, Shin H-R, Bray F, Forman D, Mathers C, Parkin DM. Estimates of worldwide burden of cancer in 2008: GLOBOCAN 2008. Int J Cancer. 2010; 127:2893-917.

3. Kaur RP, Vasudeva K, Kumar R, Munshi A. Role of p53 gene in breast Cancer: focus on mutation Spectrum and therapeutic strategies. Curr Pharm Des. 2018;24:3566-75.

4. Gallardo-Alvarado LN, Tusié-Luna MT, Tussié-Luna MI, et al. Prevalence of germline mutations in the TP53 gene in patients with early-onset breast cancer in the Mexican population. BMC Cancer. 2019;19:118.

5. Diakite B, Kassogue Y, Dolo G, Kassogue O, Keita ML, Joyce B, et al. Association of PIN3 16-bp duplication polymorphism of TP53 with breast cancer risk in Mali and a meta-analysis. BMC Med Genet. 2020;21:142.

6. Aubrey BJ, Strasser A. Kelly GLTumor-suppressor functions of the TP53 pathway. Cold Spring HarbPerspect Med. 2016;6:a026062.

7. Damineni S, Rao VR, Kumar S, et al. Germline mutations of TP53 gene in breast cancer. Tumour Biol. 2014:35:9219-27.

8. Mhawech P, Kinkel K, Vlastos G, Pelte M-F. Ovarian carcinomas in endometriosis: an immunohistochemical and comparative genomic hybridization study. Int J GynecolPathol. 2002;21:401-6.

9. Sagne C, Marcel V, Amadou A, Hainaut P, Olivier M, Hall J. A meta-analysis of cancer risk associated with the TP53 intron 3 duplication polymorphism (rs17878362): geographic and tumor-specific effects. Cell Death Dis. 2013;4 e492.

10. Kung CP, Leu Jl, Basu S, et al. The P72R polymorphism of p53 predisposes to obesity and metabolic dysfunction. Cell Rep. 2016;14:2413-25.

11. Zhou Y, Li N, Zhuang W, Liu G-J, Wu T-X, Yao X, et al. P53 codon 72 polymorphism and gastric cancer: a meta-analysis of the literature. Int J Cancer. 2007;121:1481-6.

12. Menzel H-J, Sarmanova J, Soucek P, Berberich R, Grünewald K, Haun M, et al. Association of NQO1 polymorphism with spontaneous breast cancer in two independent populations. Br J Cancer. 2004;90:1989-94.

13. Akkiprik M, Sonmez O, Gulluoglu BM, Caglar HB, Kaya H, Demirkalem P, et al. Analysis of p53 gene polymorphisms and protein over-expression in patients with breast cancer. Pathol Oncol Res. 2009;15:359-68.

14. Krivokuca AM, Malisic EJ, Dobricic JD, Brotto KV, Cavic MR, Jankovic RN, et al. RAD51 135G>C and TP53 Arg72Pro polymorphisms and susceptibility to breast cancer in Serbian women. Familial Cancer. 2014;13(2):173-80.
15. Dahabreh IJ, Schmid CH, Lau J, Varvarigou V, Murray S, Trikalinos TA Genotype misclassification in genetic association studies of the rs1042522 TP53 (Arg72Pro) polymorphism: a systematic review of studies of breast, lung, colorectal, ovarian, and endometrial cancer. Am J Epidemiol. 2013;177: 1317-25.

16. Bisof V, Salihović MP, Narancić NS, Skarić-Jurić T, Jakić-Razumović J, Janićijević B, et al. TP53 gene polymorphisms and breast cancer in Croatian women: a pilot study. Eur J Gynaecol Oncol. 2010;31:539-44.

17. Habyarimana T, Attaleb M, Mugenzi P, Mazarati JB, Bakri Y, El Mzibri M. Association of p53 codon 72 polymorphism with breast Cancer in a Rwandese population. Pathobiology. 2018;85:186-91.

18. DerSimonian R, Laird N. Meta-analysis in clinical trials. Control Clin Trials. 1986;7:177-88.

19. Higgins JPT. In: Green S, editor. Cochrane Handbook for Systematic Reviews of Interventions Version 5.1.0 [updated March 2011]: The Cochrane Collaboration; 2011. Available from http://handbook.cochrane.org.

20. Egger M, Davey Smith G, Schneider M, Minder C. Bias in meta-analysis detected by a simple, graphical test. BMJ. 1997;315:629-34.

21. Alshatwi AA, Hasan TN, Shafi G, Alsaif MA, Al-Hazzani AA, Alsaif AA. A singlenucleotide polymorphism in the TP53 and MDM-2 gene modifies breast cancer risk in an ethnic Arab population. Fundam Clin Pharmacol. 2012;26: 438-43.

22. Ayoubi SE, Elkarroumi M, El Khachibi M, Hassanildrissi $H$, Ayoubi $H$, Ennachit $\mathrm{S}$, et al. The 72Pro variant of the tumor protein 53 is associated with an increased breast Cancer risk in the Moroccan population. Pathobiology. 2018;85:247-53.

23. Buyru N, Tigli H, Dalay N. P53 codon 72 polymorphism in breast cancer. Oncol Rep. 2003;10:711-4

24. Cherdyntseva NV, Denisov EV, Litviakov NV, Maksimov VN, Malinovskaya EA, Babyshkina NN, et al. Crosstalk between the FGFR2 and TP53 genes in breast cancer: data from an association study and epistatic interaction analysis. DNA Cell Biol. 2012;31:306-16.

25. Costa S, Pinto D, Pereira D, Rodrigues H, Cameselle-Teijeiro J, Medeiros R, et al. Importance of TP53 codon 72 and intron 3 duplication 16bp polymorphisms in prediction of susceptibility on breast cancer. BMC Cancer. 2008:8:32.

26. Cox DG, Deer D, Guo Q, Tworoger SS, Hankinson SE, Hunter DJ, et al. The p53 Arg72Pro and MDM2-309 polymorphisms and risk of breast cancer in the nurses' health studies. Cancer Causes Control. 2007;18:621-5.

27. Denisov EV, Cherdyntseva NV, Litvyakov NV, Slonimskaya EM, Malinovskaya EA, Voevoda Ml, et al. TP53 mutations and Arg72Pro polymorphism in breast cancers. Cancer Genet Cytogenet. 2009;192:93-5.

28. Ebner F, Schremmer-Danninger E, Rehbock J. The role of TP53 and p21 gene polymorphisms in breast cancer biology in a well specified and characterized German cohort. J Cancer Res Clin Oncol. 2010;136:1369-75.

29. Hossain A, Murshid GMM, MNH Z, Islam F, Sultana R, Sultana T, et al. TP53 codon 72 polymorphism and breast cancer risk in Bangladeshi population. Breast Cancer. 2017;24:571-8.

30. Isakova J, Talaibekova E, Aldasheva N, Vinnikov D, Aldashev A. The associationof polymorphic markers Arg399GIn of XRCC1 gene, Arg72Pro of TP53 gene and T309Gof MDM2 gene with breast cancer in Kyrgyz females. BMC Cancer. 2017;17(1):758.

31. Katiyar S, Thelma BK, Murthy NS, Hedau S, Jain N, Gopalkrishna V, et al. Polymorphism of the p53 codon 72 Arg/pro and the risk of HPV type 16/ 18-associated cervical and oral cancer in India. Mol Cell Biochem. 2003;252: 117-24.

32. Li T, Lu ZM, Guo M, Wu QJ, Chen KN, Xing HP, et al. p53 codon 72 polymorphism (C/G) and the risk of human papillomavirus-associated carcinomas in China. Cancer. 2002;15(95):2571-6.

33. Ma H, Hu Z, Zhai X, Wang S, Wang X, Qin J, et al. Joint effects of single nucleotide polymorphisms in P53BP1 and p53 on breast cancer risk in a Chinese population. Carcinogenesis. 2006;27:766-71.

34. Sharma S, Sambyal V, Guleria K, Manjari M, Sudan M, Uppal MS, et al. TP53 polymorphisms in sporadic north Indian breast cancer patients. Asian Pac J Cancer Prev. 2014;15:6871-9.

35. Song F, Zheng H, Liu B, Wei S, Dai H, Zhang L, et al. An miR-502-binding site single-nucleotide polymorphism in the 3 '-untranslated region of the SET8 gene is associated with early age of breast cancer onset. Clin Cancer Res. 2009;15:6292-300.

36. Sprague BL, Trentham-Dietz A, Garcia-Closas M, Newcomb PA, Titus-Ernstoff L, Hampton JM, et al. Genetic variation in TP53 and risk of breast cancer in a population-based case control study. Carcinogenesis. 2007;28:1680-6. 
37. Wang-Gohrke S, Becher H, Kreienberg R, Runnebaum IB, Chang-Claude J. Intron 316 bp duplication polymorphism of p53 is associated with an increased risk for breast cancer by the age of 50 years. Pharmacogenetics. 2002;12:269-72.

38. Zhang W, Jin MJ, Chen K. Association of p53 polymor-phisms and its haplotypes with susceptibility of breast cancer. Zhejiang Da XueXue Bao Y Xue Ban. 2007;36:561-6.

39. Arfaoui A, Douik H, Kablouti G, Chaaben AB, Handiri N, Zid Z, et al. Role of p53 Codon72 SNP in breast Cancer risk and Anthracycline resistance. AnticancerRes. 2015:35:1763-9.

40. Faghani M, Nikbahkt M, Salehi M, Rabbani M, Talebi A, Soleima-ni B, et al. Study of p53 polymorphism at codon 72 in patients of breast cancer in Isfahan. J Isfahan Med School. 2007;25:26-33.

41. Chabnaz S, Ahmed MU, Islam MS, Islam MR, Al-Mamun MM, Islam MS, et al. Breast cancer risk in relation to TP53 codon 72 and $\mathrm{CDH} 1$ gene polymorphisms inthe Bangladeshi women. Tumour Biol. 2016;37:7229-37.

42. Yadav P, Masroor M, Tanwer K, Mir R, Javid J, Ahmad I, et al. Clinical significance of TP53 (R72P) and MDM2 (T309G) polymorphisms in breast cancer patients. Clin Transl Oncol. 2016;18:728-34.

43. Veronesi U, Boyle P, Goldhirsch A, Orecchia R, Viale G. Breast cancer. Lancet. 2005:365:1727-41.

44. Yager JD, Davidson NE. Estrogen carcinogenesis in breast cancer. N Engl J Med. 2006;354:270-82.

45. Stracquadanio G, Wang X, Wallace MD, Grawenda AM, Zhang P, Hewitt J, et al. The importance of p53 pathway genetics in inherited and somatic cancer genomes. Nat Rev Cancer. 2016;16:251-65.

46. Candeias MM, Malbert-Colas L, Powell DJ, Daskalogianni C, Maslon MM, Naski N, et al. P53 mRNA controls p53 activity by managing Mdm2 functions. Nat Cell Biol. 2008;10:1098-105.

47. Dumont P, Leu Jl, Della Pietra AC 3rd, George DL, Murphy M. The codon 72 polymorphic variants of p53 have markedly different apoptotic potential. NatGenet. 2003;33:357-65.

48. Rohaly G, Chemnitz J, Dehde S, Nunez AM, Heukeshoven J, Deppert W, et al. A novel human p53 isoform is an essential element of the ATR-intra-S phase checkpoint. Cell. 2005;122:21-32.

49. Basu S, Gnanapradeepan K, Barnoud T, Kung CP, Tavecchio M, et al. Mutant p53 controls tumor metabolism and metastasis by regulating PGC-1a. Genes Dev. 2018;32:230-43.

50. Jafrin S, Aziz MA, Anonna SN, Akter T, Naznin NE, Reza S, et al. Association of TP53 codon 72 Arg>pro polymorphism with breast and lung Cancer risk in the south Asian population: a meta-analysis. Asian Pac J Cancer Prev. 2020;21:1511-9.

51. Akhter N, Dar SA, Chattopadhyay S, Haque S, Anwer R, Wahid M, et al. Impact of p53 arg72pro SNP on breast Cancer risk in north Indian population. Curr Genomics. 2018;19(5):395-410..

52. Khan MH, Khalil A, Rashid H. Evaluation of the p53 Arg72Pro polymorphism and its association with cancer risk: aHuGE review and meta-analysis. Genet Res (Camb). 2015;97:e7.

53. Hou J, Jiang Y, Tang W, Jia S. p53 codon 72 polymorphism and breast cancer risk: A meta-analysis. Exp Ther Med. 2013;5:1397-402 2013.

54. Zhuo W, Zhang Y, Xiang Z, Cai L, Chen Z. Polymorphisms of TP53 codon 72 with breast carcinoma risk: evidence from 12226 cases and 10782 controls. J Exp Clin Cancer Res. 2009;28:115.

55. Francisco G, Menezes PR, Eluf-Neto J, Chammas R. Arg72Pro TP53 polymorphism and cancer susceptibility: a comprehensive meta-analysis of 302 case-control studies. Int J Cancer. 2011;129:920-30.

56. Ma Y, Yang J, Liu Z, Zhang $P$, Yang Z, Wang Y, et al. No significant association between the TP53 codon 72 polymorphism and breast cancer risk: a meta-analysis of 21 studies involving 24,063 subjects. Breast Cancer Res Treat. 2011;125:201-5.

57. Gonçalves ML, Borja SM, Cordeiro JABL, Saddi VA, Ayres FM, Vilanova-Costa CAST, et al. Association of the TP53 codon 72 polymorphism and breast cancer risk: a meta-analysis. Springerplus. 2014;3:749.

58. Thomas D. Gene-environment-wide association studies: emerging approaches. Nat Rev Genet. 2010;11:259-72.

59. Wood AR, Hernandez DG, Nalls MA, Yaghootkar H, Gibbs JR, Harries LW, et al. Allelic heterogeneity and more detailed analyses of known loci explain additional phenotypic variation and reveal complex patterns of association. Hum Mol Genet. 2011;20:4082-92.
60. Rosenberg NA, Huang L, Jewett EM, Szpiech ZA, Jankovic I, Boehnke M. Genome-wide association studies in diverse populations. Nat Rev Genet. 2010;11:356-66.

61. Murphy ME, Liu S, Yao S, Huo D, Liu Q, Dolfi SC. At al. A functionally significant SNP in TP53 and breastcancer risk in African-American women. NPJ. Breast Cancer. 2017;3:5.

62. Ohayon T, Gershoni-Baruch R, Papa MZ, Distelman Menachem T, Eisenberg Barzilai S, Friedman E. The R72P P53 mutation is associated with familial breast cancer in Jewish women. Br J Cancer. 2005;92:1144-8.

63. Henríquez-Hernández LA, Murias-Rosales A, Hernández González A, Cabrera De León A, Díaz-Chico BN, Mori De Santiago M, et al. Gene polymorphisms in TYMS, MTHFR, p53 and MDR1 as risk factors for breast cancer: a casecontrol study. Oncol Rep. 2009:22:1425-33.

64. Papadakis EN, Dokianakis DN, Spandidos DA. p53 codon 72 polymorphism as a risk factor in the development of breast cancer. Mol Cell Biol Res Commun. 2000;3:389-92.

65. Noma C, Miyoshi Y, Taguchi T, Tamaki Y, Noguchi S. Association of p53 genetic polymorphism (Arg72Pro) with estrogen receptor positive breast cancer risk in Japanese women. Cancer Lett. 2004;210:197-203.

66. Damin APS, Frazzon APG, Damin DC, Roehe A, Hermes V, Zettler C, et al. Evidence for an association of TP53 codon 72 polymorphism with breast cancer risk. Cancer Detect Prev. 2006;30:523arf-9.

67. Mahasneh AA, Abdel-Hafiz SS. Polymorphism of p53 gene in Jordanian population and possible associations with breast cancer and lung adenocarcinoma. Saudi Med J. 2004;25:1568-73.

68. Nordgard SH, Alnaes GIG, Hihn B, Lingjaerde OC, Liestøl K, Tsalenko A, et al. Pathway based analysis of SNPs with relevance to 5-FU therapy: relation to intratumoral mRNA expression and survival. Int J Cancer. 2008;123:577-85.

69. Rajkumar T, Samson M, Rama R, Sridevi V, Mahji U, Swaminathan R, et al. TGFbeta1 (Leu10Pro), p53 (Arg72Pro) can predict for increased risk for breast cancer in south Indian women and TGFbeta1 pro (Leu10Pro) allele predicts response to neo-adjuvant chemo-radiotherapy. Breast Cancer Res Treat. 2008;112(1):81-7.

70. Singh V, Rastogi N, Mathur N, Singh K, Singh MP. Association of polymorphism in MDM-2 and p53 genes with breast cancer risk in Indian women. Ann Epidemiol. 2008;18:48-57.

71. Alawadi S, Ghabreau L, Alsaleh M, Abdulaziz Z, Rafeek M, Akil N, et al. P53 gene polymorphisms and breast cancer risk in Arab women. Med Oncol 2011;28:709-15.

72. Aoki MN, da Silva do Amaral Herrera AC, Amarante MK, do Val Carneiro JL, MHP F, MAE W. CCR5 and p53 codon 72 gene polymorphisms: implications in breast cancer development. Int J Mol Med. 2009;23:429-35.

73. Hrstka R, Beranek M, Klocova K, Nenutil R, Vojtesek B. Intronic polymorphisms in TP53 indicate lymph node metastasis in breast cancer. Oncol Rep. 2009;22:1205-11.

74. Kazemi M, Salehi Z, Chakosari RJ. TP53 codon 72 polymorphism and breast cancer in northern Iran. Oncol Res. 2009;18:25-30.

75. Suresh K, Venkatesan R, Chandirasekar R, Kumar BL, Sasikala K. Association of Trp53 arg72pro polymorphic variants with breast cancer - a case control study in south Indian population. Biol Med. 2011;3:15-22.

\section{Publisher's Note}

Springer Nature remains neutral with regard to jurisdictional claims in published maps and institutional affiliations.

\section{Ready to submit your research? Choose BMC and benefit from:}

- fast, convenient online submission

- thorough peer review by experienced researchers in your field

- rapid publication on acceptance

- support for research data, including large and complex data types

- gold Open Access which fosters wider collaboration and increased citations

- maximum visibility for your research: over $100 \mathrm{M}$ website views per year

At BMC, research is always in progress.

Learn more biomedcentral.com/submissions 